UDC: 321.01:342.228

DOI: https://doi.org/10.32689/2617-

2224-2020-1(21)-177-191

Мамонтова Елла Вікторівна,

доктор політичних наук, професор, професор кафедри регіональної політики та публічного адміністрування; Одеський регіональний інститут державного управління нащіональної академіі державного управління при президентові Украӥни, 65009, м. Одеса, вул. Генуезька, 22, тел.: +38 (050)336 25 54, general@oridu.odessa.ua, e-mail aвmopa: arhitektonica@gmail.com

ORCID: 0000-0003-2761-8217

Мамонтова Элла Викторовна, доктор политических наук, профессор, профессор кафедры региональной политики и публичного администрирования, Одесский региональный институт государственного управления Нащиональной

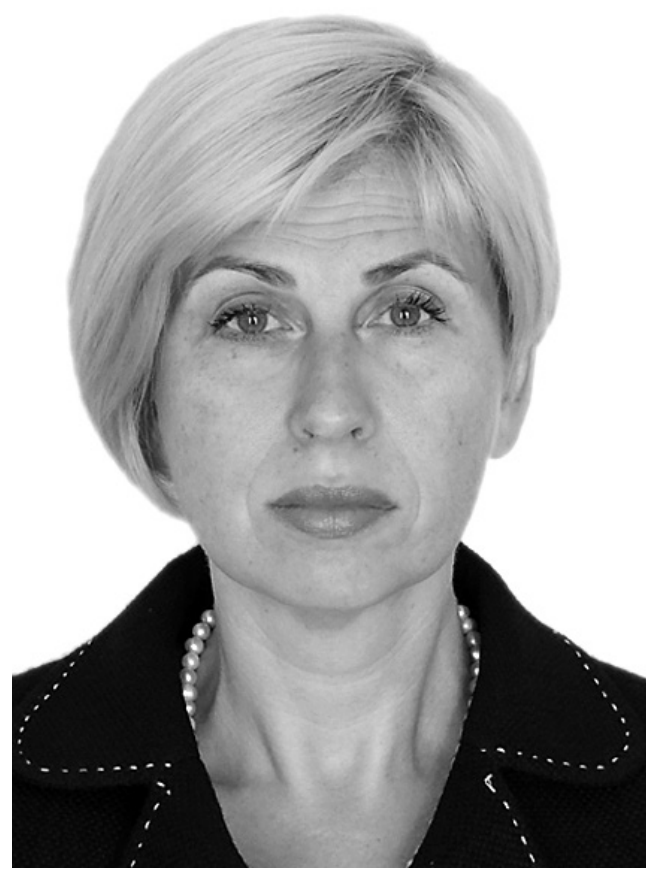
академии государственного управления при президенте Украины, 65009, г. Одесса, ул. Генуэзская, 22, тел.: +38 (050)336 25 54, general@oridu.odessa.ua,e-mail aвmopa: arhitektonica@gmail.com

ORCID: 0000-0003-2761-8217

Mamontova Ella Victorovna,

Doctor of Political sciences, Professor, Professor of Regional Policy and Public Administration Chair, Odessa Regional Institute for Public Administration of the NAPA under the President of Ukraine, 65009, Odessa, Str. Henuezka, 22, tel.: +38 (050) 336 25 54. general@oridu.odessa.ua, e-mail: arhitektonica@gmail.com

\title{
АРХЕТИПОВІ ПРОЕКЦІї АРХАЇЧНИХ ДУХОВНИХ ПРАКТИК НА СИМВОЛІЧНИЙ ЛАНДШАФТ ПОСТПОЛІТИКИ
}

Анотація. Досліджується актуальна тенденція сучасного постіндустріального світу, пов'язана із символізацією суспільно-політичних відносин. Символізація трактується як перетворення на символ будь-якої дії, що свідомо здійснюється її суб'єктом. Показано, що класичні підходи до концептуалізації символу як складової політики розглядають його у координатах традиційного політичного порядку, побудованого на інституціональних засадах 
та усталених ідеологемах. Зазначено, що у добу постсучасності місце релігії та ідеології як ключових джерел символічного виробництва та інструментів смислоутворення, займає нова техніка - політичний соціосеміозис. Його сутність полягає у механізмі універсалізації практик інтерпретації політичної реальності та їі феноменів, наслідком якого виступає символізм політичного простору.

Досліджується ресурсний потенціал соціосеміозису в ситуації постполітики. Посполітика визначається як перманентний процес деконструкції реальності з підміною сутності на їі знак, символ, найменування, в результаті чого відбувається автономізація символу. Причини цього криються не тільки у четвертій інформаційній революції, з їі новими комунікативними практиками, але й в онтологічному характері самого явища.

Це зумовлює звернення до первинних джерел феномену символізації. Показано, що його виникнення припадає на доісторичні часи та зумовлено такими принципами первісного міфологічного мислення як синкретизм, генетизм та етіологізм. Символотворчий потенціал міфологічних технік управління суспільством розглянуто на прикладі тотемізму та фетишизму - культових практик неорганізованих архаїчних релігій.

Доведено, що тотемізм та фетишизм на сьогодні широко представлені у символічному ландшафті постполітики як їх архетипові проекції. Як похідний від ритуалу фетиш безпосередньо стосується тотему, а разом вони складають підоснову усієї предметної політичної символіки ідентичності: від фізико-географічних об’єктів, репрезентантів світу фауни і флори до архітектури, монументалістики та атрибутів державного суверенітету як предметів культу та колективних оберегів.

Ключові слова: символ, символізація, соціосеміозис, міф, постполітика, тотем, тотемізм, фетиш, фетишизм, архетипова проекція.

\section{АРХЕТИПИЧЕСКИЕ ПРОЕКЦИИ АРХАИЧНЫХ ДУХОВНЫХ ПРАКТИК НА СИМВОЛИЧЕСКИЙ ЛАНДШАФТ ПОСТПОЛИТИКИ}

Аннотация. Исследуется актуальная тенденция современного постиндустриального мира, связанная с символизацией общественно-политических отношений. Символизация трактуется как превращение в символ любого действия, сознательно осуществляемого его субъектом. Показано, что классические подходы к концептуализации символа как нетъемлемой части политики, рассматривают его в координатах традиционного политического порядка, построенного на институциональных основах и устоявшихся идеологемах. Отмечено, что в эпоху постсовременности место религии и идеологии как ключевых источников символического производства и инструментов смыслообразования, занимает новая техника - политический социосемиозис. Его сущность заключается в механизме универсализации практик интерпретации политической реальности и ее феноменов, итогом чего выступает символизм политического пространства. 
Исследуется ресурсный потенциал социосемиозиса в ситуации постполитики, которая определяется как перманентный процесс деконструкции реальности с подменой сущности на ее знак, символ, наименование, в результате чего происходит автономизация символа. Причины этого кроются не только в четвертой информационной революции с ее новыми коммуникативными практиками, но и в онтологическом характере самого явления. Это обусловливает обращение к первичным источникам феномена символизации. Показано, что его возникновение приходится на доисторическую эпоху и обусловлено такими принципами первобытного мифологического мышления как синкретизм, генетизм и етиологизм. Символический потенциал мифологических техник управления обществом рассмотрен на примере тотемизма и фетишизма - культовых практик неорганизованных архаических религий.

Доказано, что тотемизм и фетишизм и сегодня широко представлены в символическом ландшафте постполитики в качестве их архетипических проекций. Как производный от ритуала, фетиш имеет непосредственное отношение к тотему, а вместе они составляют подоплеку всей предметной политической символики идентичности: от физико-географических объектов, репрезентантов мира фауны и флоры до архитектуры, монументалистики и атрибутов государственного суверенитета как предметов культа и коллективных оберегов.

Ключевые слова: символ, символика, социосемиозис, миф, постполитика, тотем, тотемизм, фетиш, фетишизм, архетипическая проекция.

\title{
ARCHETYPAL PROJECTIONS OF ARCHAIC SPIRITUAL PRACTICES INTO THE SYMBOLIC LANDSCAPE OF POST-POLITICS
}

\begin{abstract}
The current trend of the modern post-industrial world associated with the symbolization of social and political relations is investigated. Symbolization is interpreted as the transformation into a symbol of any action consciously carried out by its subject. It is shown that the classical approaches to the conceptualization of the symbol as a component of politics consider it are considered in the coordinates of the traditional political order, built on institutional principles and established ideologems. It is noted that in the era of postmodernity, the place of religion and ideology as the key sources of symbolic production and tools of creation is occupied by a new technique-political social semiosis. Its essence lies in the mechanism of universalization of practices of interpretation of political reality and its phenomena, the consequence of which is the symbolism of political space.

The resource potential of sociosemiosis in the situation of post-politics is investigated. Post-politics is defined as a permanent process of deconstruction of reality with the substitution of an entity for its sign, symbol, name, resulting in the autonomization of the symbol. The reasons for this lie not only in the fourth information revolution, with its new communicative practices, but also in the ontological nature of the phenomenon itself.
\end{abstract}


This predetermines the appeal to the primary sources of the phenomenon of symbolization. It is shown that its origin falls on prehistoric times and is caused by such principles of primitive mythological thinking as syncretism, genetics and etiology. The symbol-forming potential of mythological techniques of society management is considered on the example of totemism and fetishism-cult practices of unorganized archaic religions.

It is proved that totemism and fetishism are still widely represented in the symbolic landscape of post-politics as their archetypal projections. As a derivative of the ritual, the fetish is directly related to the totem, and together they form the background of the entire subject of political symbolism of identity: from physical and geographical objects, representatives of the world of fauna and flora to architecture, monumentalism and attributes of state sovereignty as objects of worship and collective amulets.

Keywords: symbol, symbolization, sociosemiosis, myth, post-politics, totem, totemism, fetish, fetishism, archetypal projection.

Постановка проблеми. На сьогодні світове експертне товариство уважно спостерігає за парадигмальними зрушеннями у світосприйнятті постіндустріального суспільства, які, зокрема, пов’язані із тенденцією символізації суспільно-політичних відносин, під якою ми пропонуємо розуміти перетворення на символ будь-якої дії, що свідомо здійснюється їі суб’єктом. В ситуації постсучасності зразка XXI століття символи вже не віддзеркалюють соціальну реальність, але стають самою реальністю для спільноти. Так, в основі формування, фіксації та відтворення нації та держави завжди закладається певна система символоформ та символодій, які через створення національного символічного простору, через зміцнення символічного капіталу власної держави та через конкуренцію з символічними універсумами інших культур, держав та геополітичних утворень, позначають ареал розповсюдження і ступень захищеності національного та державного суверенітету.

Такий величезний креативний потенціал і спроможність народжувати нові смисли, що ведуть до переформатування простору соціально-владних відносин, актуалізують дослідження природи символу як феномену політичної реальності та інструменту політико-управлінського впливу. Адже в умовах, коли в наслідок глобальних трансформацій відбувається послаблення традиційних устоїв державного регулювання соціально-політичних відносин, які здебільшого носять інституційний характер, звернення до арсеналу нетрадиційних ресурсів в політиці є актуальною вимогою часу. Одним 3 таких ресурсів і виступає символ.

Аналіз останніх досліджень та публікацій. Безумовно, соціальна природа символу та його політико-управлінський потенціал від- 
давна цікавили дослідників. Так, філософськи спроби осмислення символу як складової соціально-політичного буття пройшли тривалий шлях від архаїчних спроб осягнення даного феномену у добу античності до його інтерпретації у раціоналістичних та естетичних концепціях Просвітництва i, в цілому, не виходять за межі загальноприйнятої періодизації історії самої філософії.

Починаючи 3 другої половини XIX ст. активізуються процеси концептуалізації символу, які на сьогодні вже охопили широке коло дослідницьких напрямків та шкіл, сформованих у рамках соціології (П. Блау, Г. Блумер, Дж. Г. Мід, Дж. Хоманс, Т. Шибутані), антропології (Ф. Боас, К. Гірц, Дж. Лаббок, І. Льюіс, Б. Малиновський, М. Мід, М. Mocc, А. Ф. Редкліфф-Браун, Е. Тайлор, Іп. Тен, Л. Уайт, Дж. Фрезер), аналітичної психології (З. Фрейд, Е. Фромм, К. Г. Юнг), культурософії (Е. Касірер, Г. Коген, С. К. Лангер, О. Шпенглер), герменевтики (Г. Г. Гадамер, П. Рикер), феноменології (Е. Гуссерль, О. Лосєв, П. Флоренський), семіотики (У. Еко, Ю. Лотман, Ч.У. Морріс, Ч. Пірс, Ф. де Сосюр, Г. Фреге), соціолінгвістики, структурного функціоналізму та постструктуралізму (Р. Барт, Ж. Лакан, Л. Леві-Брюль, К. Леві-Стросс, Е. Ортига, Ж. Піаже, В. Пропп, У. Уорнер, М. Фуко) тощо. Втім, остаточне перенесення символу та його соціально-владної ролі як категорій теоретико-методологічного осмислення із площини, що задається координатами “означаюче - означуване” у сферу політичного, відбулося у межах соціодрама- тургії (К. Берк, Е. Гофман, Х. Данкен, Дж. Мак-Колл), комунікативістики (Ж. Дельоз, Ж.-Ф. Ліотар, Н. Луман, Ю. Хабермас) та постмодернізму (П. Бергер, Ж. Бодрійяр, П. Бурдьє, Е. Гіденс, Н. Еліас, Т. Лукман, А. Шюц).

Останні течії здійснили помітний вплив на формування нових дослідницьких підходів, спрямованих на вивчення власне символічного аспекту політики, а саме: політико-культурологічного (Т. Арнольд, А. Вілдавскі, М. Едельман, Р. Елліс, Л. Дітмер, М. Дуглас, Дж. Кауфман, В. Радаєв, Р.Такер, В. Тернер, М. Томпсон, А. Уайтхед) та політико-комунікативного (К. Дойч, Е. Канетті, Г. Лассуел, Г. Почепцов, Ф. Тенніс). У контексті технологізації процесів управління суспільством символічна компонента політики розглянута у роботах іноземних (Дж. Адаір, Е. Аронсон та Е. Праткінс, Г. Атаманчук, Р. Белла, А. Май, В. Сергєєв, С. Поцелуєв, Дж. Пфеффер, В. Соловйов) та вітчизняних (Е. Афонін, В. Горбатенко, Ф. Кирилюк, Т. Ляпіна, Г. Почепцов) дослідників.

Втім, не зважаючи на широкий спектр підходів до концептуалізації символу та символічного як складових політики, усі вони, у своїй переважній більшості, по-перше, носять фрагментарний характер, по-друге, як-правило, зосереджуються на соціокультурних аспектах питання, та, по-третє, розглядають його у координатах традиційного політичного порядку, побудованого на інституціональних засадах та усталених ідеологемах. Додамо також, що поза зоною уваги більшості дослідників залишається запит на вивчення ре- 
сурсного потенціалу символу в ситуації постполітики, яку характеризує, між іншим, переміщення акценту зі змістовного на формальне, з актуального на віртуальне, з сутності на iii знак. Результатом даного перманентного процесу деконструкції $€$ абсолютизація того, що означує на тлі десакралізації або знищення того, що означається. Іншими словами, посполітичну реальність характеризує підміна смислів, явищ, імен знаками, символами, найменуваннями.

На нашу думку, причини посилення вищеописаної тенденції, яка у постіндустріальну добу призводить до автономізації символу, криються не тільки у четвертій інформаційній революції, яка подарувала людству нові комунікативні практики і завдяки Інтернет-технологіям, диджіталізації, інтерактивному спілкуванню, віртуалізації, мережевій інтеграції та кооперації зробила простого споживача інформації повноцінним співучасником процесу її вироблення, співавтором нових смислів та співтворцем нових образів. Хоча, безумовно, без технічного прогресу, який перетворив засоби масової інформації з їх лінійним впливом на аудиторію за зразком класичного авторського дискурсу доби модерну, де митець та публіка розділені просторово, статусно та функціонально, на засоби масової комунікації з їх постмодерновим “неофольклорним” залученням аудиторії у творчий процес, коли вона перетворюється на його повноправного активного співучасника, тенденція символізації не стала б трендом. Тим не менш, ми переконані, що дане явище носить онтологічний характер, що вима- гає звернення до його витоків i, перед усім, до найдавніших духовних практик.

Мета статті полягає у виявленні специфіки культових практик неорганізованих архаїчних релігій у контексті їх символотворчого потенціалу та окресленні їх архетипових проекцій на символічний ландшафт постполітики.

Виклад основного матеріалу дослідження. Знайомство 3 теоретико-методологічними підвалинами вивчення символу як детермінанти соціально-владних відносин і ресурсу панування дозволяє стверджувати, що у якості предмету розумової рефлексії символ вперше з'являється у античному філософському дискурci. Втім, приступаючи до аналізу природи символу та виявлення його соціотворчого потенціалу, слід зазначити, що брати за точку відліку античність буде не зовсім точним. Адже історія феномена (об'єкта, явища) та історія поняття (терміна) ніколи не бувають тотожними. 3 грецької античності починається історія осмислення символу у рамках європейської інтелектуальної традиції, з характерними для неї раціоцентризмом та системою бінарних опозицій. В той час, як історія символу як феномену та універсальної категорії культури, зокрема й культури політико-управлінських відносин, сягає у найдавніші часи первісних суспільств. Людина перейшла до раціонального осмислення понять тільки після того, як нею було пройдено стадію інтуїтивного, чуттевого сприйняття символів і знаків.

Дана стадія є відправною точкою тисячолітнього процесу еволюції форм політичної організації суспіль- 
ства, який, зокрема, може бути розглянутий і у фокусі парадигмальних змін різноманітних символічних систем смислопородження: міфології, релігії, ідеології, соціосеміозісу. Припускаючи, що саме міф стає історично-першим інструментом структуризації соціального простору і первинним джерелом символічного виробництва, зазначимо, що хронологічні рамки існування міфологічного світу охоплюють найбільш тривалий період історії людства від доісторичних часів до падіння античного світу, що зумовлює поетапність його розвитку та варіативність форм символічного впливу. Відповідно до стадій магістрального історичного процесу формування держави як форми політичної організації суспільства, ми пропонуємо виділити три етапи становлення суспільства міфологічного типу: магічний (архаїчно організоване суспільство додержавної доби); сакральний (ідеократичне суспільство Давньосхідних деспотій); раціонально-містичний (громада античного полісу).

Саме первісне суспільство, як історично перший тип міфологічного суспільства, створює міфологічний комплекс, який у синкретичних візуально-вербальних символоформах та символодіях виступає інструментом осягнення світу, його пояснення та відтворення у архетипових знаках і образах, чим формує норми та зразки соціальної поведінки.

Невід'ємною складовою формування міфологічного світогляду став процес зародження у свідомості людини знаку та символу. На нашу думку, виникнення феномену символізації зумовлене такими принципа- ми міфологічного мислення як синкретизм, генетизм та етіологізм. Так, синкретизм, який проявляється у відсутності чіткої роздільності об'єкту і суб'єкту, імені і речі, простору і часу, робить їх знаками один одного, чим і запускає механізм символізації. Генетизм, через видання походження предмету за його сутність, замінює причинно-слідчі відносини прецедентом і вводить таким чином у арсенал управління суспільством інструменти імітації та повтору. Етіологізм, у пошуках першопричин існування індивіда і світу, відкриває людині не тільки смисл життя, але й спосіб його відтворення, завдяки чому міф сприймається як проект майбутнього і задає вектори соціального розвитку.

Наслідком розповсюдження такого типу соціального моделювання стає зародження у міфологічному суспільстві магічного типу історично першого, архетипового за структурою i системоутворюючого за функціональним навантаженням символічного комплексу, який ми класифікували як комплекс ідентифікації. Фактором його становлення стали: а) закріплення за міфом статусу нормативної необхідності; б) звернення до імітації як механізму регулювання соціальної взаємодії; в) вираження та прояв світоглядної єдності людини і природи, що притаманна міфологічному типу світосприйняття у явищах тотемізму, фетишизму та анімізму; г) визнання магії пануючою формою смислових та соціальних взаємин у міфологізованому просторі.

Кожен із названих факторів надав поштовху до зародження та струк- 
туризації архетипних першоформ та першодій, які згодом буде покладено у основу символічного комплексу ідентифікації, без якого і сьогодні не можлива реалізація державотворчого проекту, що доводить досвід багатьох країн, в тому числі, нажаль, і України.

Найбільш показовим з точки зору виявлення символотворчого потенціалу міфологічних технік управління суспільством є такі культові практики неорганізованих архаїчних релігій, як тотемізм та фетишизм. В ї основі - притаманна первісному мисленню світоглядна єдність людини і природи. Так, закони, за якими існує світ живої природи, як-то народження та смерть, об’єднання у пари та виховання потомства тощо, через механізм імітації фіксувалися первісною людиною у обрядах та ритуальних атрибутах - масках, татуїровках, культових предметах тощо. Паралельно з цим відчуття схожості усвідомлювалося як спорідненість із певним звіром, рослиною, природним явищем, і було покладене в основу процесу обожнення та надання їм статусу покровителів. Так, об’єкти природи поступово набували у свідомості первісної людини статусу тотемів, а предмети, що підтверджують споріднений зв'язок людини із тотемом стають фетишами.

Термін “тотем” (від “ototeman”, “oт-тотем”) прийшов у науковий лексикон із мови північноамериканських індійців оджибве і буквально перекладається як “той, що належить до клану”, “його рід”. Іншими словами, тотем - це рослина або тварина, надприродним чином пов'язана із життям групи або індивіда [1, с. 81].
Для первісної людини тотем - це, перед усім, добрий предок, прародич та покровитель. Фактологічний матеріал численних антропологічних досліджень (Р. Аткінсон, Г. Кларк, С. Коул, Д. Раймонд, Л. Ричард, Л. Морган, Е. Тайлор, Дж. Фрейзер та ін.) переконливо доводить, що майже кожний рід носив ім'я свого тотему, вибір якого був зумовлений фізико-географічним характером місцевості. I якщо спочатку тотемом групи служила справжня реальна істота - тварина, птиця, комаха, рослина, то пізніше для поклоніння достатнім стало її зображення. А згодом тотем остаточно перетворюється на символ, слово, звук.

Така система уявлень про кровноспоріднені зв'язки людського колективу із його міфічним зооантпропоморфним предком - тотемом вважається однією із найархаїчніших форм міфологічної свідомості та культу, яка отримала у науковій літературі найменування тотемізму. В його основу покладено явище, яке Л. Леві-Брюль [2] та Л. Виготський [3] визначають як партиципацію (від лат. participa-tio - участь, причетність, залучення, спроба зробити когось співучасником). Його сутність можна пояснити станом, коли члени групи (клану, роду, племені) вважають тотем своїм прямим пращуром та ідентифікують себе з ним.

Порядок такої тотемної спорідненості закріплювався за допомогою заборони - табу, що спочатку мало на меті уникнення пагубних наслідків кровозмішення як статевих стосунків із членами свого тотему, які, вірогідно, каралася смертю (К. Леві-Стросс, Л. Морган, А. Ред- 
кліфф-Браун, У. Робертсон-Смит, 3. Фрейд, Дж. Фрезер та ін.). У подальшому механізм табуювання забезпечив поступовий перехід від абсолютної індивідуальної свободи підсвідомого під тотальний контроль колективу. Ще одним найважливішим наслідком даного процесу стало те, що табу перетворилося для людини на один із самих діючих засобів досягнення самоконтролю. Отже, два головних табу тотемізму - заборона вбивства тотему та заборона інцесту, зіграли ключову роль у зародженні моралі. Більш того, табу стає першим кроком не тільки до встановлення системи моральних норм та правил, але й детермінує процес формування всієї соціальної організації та цілісної системи соціальної взаємодії.

Безумовно, більшість народів поступово втратила тотемічні уявлення, однак їхній вплив відчувався протягом усієї історії. Так, у давньогрецькому суспільстві сліди тотемізму містять міфи о кентаврах, сюжети про перетворення людей у тварин тощо. Тотемічні риси простежуються у образах богів та героїв у вірування корінних жителів Центральної та Південної Америки. Широко відомі актуальні культи священних тварин - корів, мавп, слонів, крокодилів у Індії, в яких чітко відбиваються сліди архаїчної забороні на вбивство. У європейській культурі існує табуювання насильства та знищення домашніх тварин - собаки та кошки. Відлуння тотемізму відчувається у численних фольклорних легендах про перевертнів, відьом та у персонажах сучасного кінематографічного маскульту.
Відголосом тотемізму первісного суспільства можна вважати й таке досить розповсюджене явище, як присутність у національних символічних ландшафтах символів тотемічного походження. I сьогодні певна тварина або рослина, в архетиповому образі якої сконцентровані найяскравіші риси національного характеру та з усією повнотою виявляється дух нації, часто виступають їі неофіційними символами. Нерідко об’єкти, що сприймаються як символічні обереги нації, її покровителі, охоронці, перетворюються із могутніх тотемів на загальновідомі неофіційні символи держав. Нам добре знайомі “галльській півень", "руський ведмідь”, “китайська панда”, “шведський лось”, “ліванський кедр”, “естонська волошка”, “українська калина”, “канадський кленовий лист”, “ірландська конюшина Св. Патрика” тощо.

На символічну природу тотемізму красномовно вказує перелік його соціальних функцій, які через їх архетипові проекції залишаються актуальними і донині. Це: а) об'єднання людей навколо колективно визнаного тотему (інтегративна функція); б) підкорення поведінки групи через заборони-табу, яких повинні додержуватися усі її члени (регулятивна функція); в) використання тотема під час кризових явищ, стихійних лих, війн, епідемій, катастроф (мобілізаційна функція); г) демонстрація іншим приналежності до певної групи (атрибутивна функція).

Символічна підоснова чітко простежується й у іншій архаїчній духовній практиці - у поклонінні фетишам, або фетишизмі. 
Термін “фетиш” (від португал. feitico - чаклунство, амулет) був введений у науковий лексикон на поч. XVIII ст. французьким дослідником Ш. де Броссом [4]. Втім, не зважаючи на те, що явище фетишизму доволі грунтовно вивчено (П. Гольбах, Г.В. Ф. Гегель, О. Конт, Дж. Лаббок, Е. Тайлор та ін.), воно й досі залишається предметом гострої наукової дискусії. Попри спроби відмовитися від терміну, з причини його розпливчатості та невизначеності, спільним для всіх напрямків та шкіл є розуміння того, що фетишизм (у франц. версії перекладу - fetichisme, fetichie, - ідол, талісман) - це, перед усім, поклоніння матеріальним предметам - фетишам. На наше переконання, фетишизм - це не стадія становлення релігії, і не психологічний механізм, а сукупність культових практик поклоніння неодушевленим предметам, які, у їхньому природному стані, або змінені певним чином у відповідності до призначення, складають об'єкт культу. У процесі фетишизації відбувається ототожнення соціальних та культурних функцій предмету із його природними властивостями або із природними особливостями індивіда. Для первісної людини фетишем міг стати будь-який предмет, що іï̈ вразив. Найчастіше фетишем виступали або природні об'єкти (каміння із гори, яку почитають як культову, куски дерева, частини тіла тварини, зерна тощо), або рукотворні предмети, що імітували об'єкт поклоніння - ідоли (пластичні або настінні зображення, i, навіть, тату).

Узагальнення широкого фактологічного матеріалу, викладеного у ро- ботах із антропології, культурології етнографії та історії мистецтв, дозволяє у контексті предмету нашого дослідження класифікувати фетиші як об'єктно - символічні (а) та символічно - об'єктні (б).

Під об'єктно-символічними фетишами ми пропонуємо розуміти реально існуючі предмети матеріального світу, які в наслідок фетишизації перетворюються на безпосередні об'єкти культу. На індивідуально рівні такими фетишами виступають амулет і талісман, де амулет (від. лат. amuliri - "відстороняти”, "відвертати”) - це річ, що наділяється магічними властивостями відвертати від людини біду та здатна захищати свого володаря від лиха та хвороби, а талісман (від грець. "телесма" - "посвячення”) - це оберіг, який, на відміну від амулету, ховали від чужих очей, використовуючи не для захисту від злих сил, а для залучення вдачі.

Відзначимо, що амулети і талісмани у їх архетипових проекціях супроводжують усю історію людства. Нині ïх найпоширенішими традиційними різновидами є релігійна символіка та коштовні каміння. У певному сенсі роль оберегів виконувала і ідеологічна символіка тоталітарних режимів. Так, партійний квіток члена КПРС - це не тільки офіційний документ, але й своєрідна гарантія виживання у ситуації державної монополії на владу, в тому числі й владу духовну. Звідси, культ “партквітка” у СРСР можна вважати яскравим свідченням поєднання первісних механізмів фетишизації із практиками ідеологічного впливу. Значно поповнився арсенал фетишизації у XXI ст., коли, на протидію сцієнталізму інформа- 
ційного суспільства знання та технологізації сучасного світу в цілому, активно реанімуються у їх архетипових проекціях практики окультизму, астрології, магії, неоязичництва тощо.

Щодо колективного фетишу об'єктно-символічного порядку, то він виступає як спільний та загальноприйнятий для всієї групи конкретний природний об'єкт (гора, ріка, озеро, красиве велике дерево тощо). Часто колективні фетиші мали спеціалізацію: окремі предмети поклоніння призначалися для управління часом, здоров'ям, мисливством, рибалкою тощо. Той, хто відігравав ведучу роль у їх виборі, закріплював через це свій авторитет. Як правило, дану функцію брали на себе маги, чаклуни, жерці, - люди, діяльність яких стояла у витоків процесів соціальної диференціації та формування системи відносин у координатах “управління - підкорення”.

Безспірно, вагомість ролі культових фізико-географічних об'єктів національного значення у становленні ідентифікаційного символічного комплексу кожної окремої нації $€$ архетиповою проекцією архаїчних духовних практик, заснованих на імітаційних механізмах фетишизаціiі. Досить пригадати, яке місце у фольклорі, поезії, історичному нарративі та сучасному символічному ландшафті кожного народу займають природні об’єкти (український Дніпро, польська Вісла, індійській Ганг, китайська Хуанхе, вірменський Арарат, японська Фудзіяма, українська Говерла, болгарська Шипка, грецький Олімп, бухта Халонг у В'єтнамі, мис Рока у Португалії тощо).
На відміну від об'єктно-символічних фетишів, перетворення яких на об’єкти культу здійснюється за схемою “від матеріальної форми до 11. символічного осягнення”, символічно-об'єктну групу фетишів складають витвори людини: ідоли. У буквальному перекладі із грецької ідол (eidolon) є “образом”, “подібністю”. Ідолоподібні фетиші - це зооморфічні та антропоморфічні рукотворні фігури із природних матеріалів (каміння, дерева, глини, кості тощо) або абстрактні зображення. Усі різновиди ідолів: істукани, кумири, пагоди, кам'яні баби, болвани тощо, мають знакову символічну природу i є першоформами монументалістики - однієї із складових блоку просторової символіки, який згодом, у форватері процесу інституалізації влади, займе чільне місце серед інструментів їі легітимації та ресурсів впливу на соціально-політичні процеси ідентифікації. Архетиповим проекціями таких символічно-об'єктних фетишів в сучасних національних символічних ландшафтах є знакові архітектурні культові та світські споруди, пам'ятники, монументи (Сгипетські Піраміди, афінський Акрополь, римський Колізей, собор Св. Петра у Ватикані, Тадж Махал у Агрі, Ангкор-Ват у Камбоджі, Бранденбургськи ворота у Берліні, Ейфелева башта у Парижі, башти Петронас в Куала-Лумпурі, хмарочос Бурдж-Халифа у Дубаї, Статуя Свободи в Нью-Йорку, пам'ятник Христу у Ріо-де-Жанейро тощо). Достатньо пригадали, який гучний резонанс викликала недавня пожежа у Notre Dame de Paris, коли знищення архітектурної пам'ятки набуло ста- 
тусу символічної події і було сприйнято світовою спільнотою як знак “присмерку Європи”.

Крім того, фетиші символічно-об'єктного типу тісно пов'язані із культом предків, зокрема з погребальною обрядовістю. Ше Е. Тайлор [5] відносив до сфери фетишизму погребальний обряд, як такий. Відмітимо, що прадавня звичка зберігати частини тіла померлого або його перетворення на “сосуд надприродних сил” через його повну муміфікацію (Сгипет, Перу), як прояв практики фетишизації несподівано відродилася у тоталітарних культах XX ст. (СРСР (В. Ленін), Болгарія (Т. Живков), Китай (Мао Цзедун), В'єтнам (Хо Ши Мин), Північна Корея (Кім Ір Сен)).

Як бачимо, наділення предметів магічними властивостями, їх фетишизація не зникає із трансформацією міфологічного суспільства. В наступних типах соціальної організації, заснованих на інших різновидах символічно-нормативних форм, вона продовжує залишатися важливою частиною політико-управлінського арсеналу. Так, безпосередній зв’язок простежується між фетишизмом первісної доби та релігійним культовими практиками християнства (поклоніння іконам, святим мощам), буддизму (шанування священних “ступ”), ісламу (паломництво до святих міст та “чорного каміння”).

К. Маркс аналізує явище “товарного фетишизму” у суспільстві капіталістичної формації. На його думку, самозростання вартості призводить до процесу наділення продуктів виробництва надприродними властивостями. Для Маркса фетишизм
- це елемент не стільки релігійної свідомості, скільки універсальна характеристика, притаманна для різних їі форм [6, с. 458-470]. Філософ пов'язує фетишизм із зрощенням культурно-соціальних функцій речі iз ï матеріальним субстратом і вводить поняття “товарного фетишизму”. Даний феномен, на його думку, зумовлюється упредметненням соціальних відносин та персоніфікацією речей. “Товарний фетишизм” - це персоніфікація речей та економічних категорій, і перш за все, грошей. Капітал через виробничі відносини персоніфікується у капіталісті, а наймана праця - у робітнику. Таким чином, через персоніфікацію економічних відносин закони капіталістичного виробництва проявляються як дія і воля окремих людей та груп [7, с. 80-93].

У XX та XXI ст. явище фетишизації світу речей трактується як стрижнева характеристика постіндустріального суспільства споживання і входить до предметного кола ключових тем постмодерністського дискурсу (Р. Барт, Ж. Бодрійар, М. Фуко та ін.).

Широкий діапазон застосування фетишизації у практиках політичного та управлінського впливу, окреслений актуальним соціологічним знанням (досить пригадати у цьому зв’язку концепції “візуалізаціï” В. В. Беньяміна [8, с. 235-247], “словесного фетишизму революції" П. Сорокина [9, с. 151-153], “політичного фетишизму” П. Бурдьє [10, c. 231-262]), - ще одно свідчення на користь i владного потенціалу. Не випадково, слово “культовий” міцно вкоренилося у лексиконі глобалізо- 
ваного постсучасного суспільства. Для того, щоб суб'єкт міг впливали - він повинен бути “культовим”, таким, що стає об'єктом масового поклоніння з причини видатних досягнень у певній сфері виробництва смислів - культурі, мистецтві, науці, політиці. Адже сьогодні тільки культовим фігурам під силу підкорити, інтегрувати та мобілізувати широкі маси населення та управляти ними.

Саме так і функціонує ключовий механізм постполітики, який полягає у абсолютизації знаку і символу при тотальному знищенні інституцій, норм і традицій, в результаті чого до влади приходять віртуальні партії та політики-голограми.

Висновки і перспективи подальших досліджень. Усе зазначене дозволяє зробити деякі узагальнення. Реальна влада у суспільстві - це завжди влада нематеріальна. Адже соціальний світ, складовою якого є і підсистема політики, є надзвичайно багатомірним простором. Цей простір, розмічений, сконструйований та побудований за принципом диференціації, формується сукупністю діючих факторів, володіння якими і $є$ запорукою влади у цьому універсумі. Виходячи з вищезазначеного, присвоєння дефіцитних матеріальних та нематеріальних благ, де останні визначаються як культурно-символічні ресурси, як і встановлення контролю за їх подальшим розподілом у процесі соціальної взаємодії, є фундаментальним джерелом політичної влади та управління. Інакше кажучи, відносини влади у суспільстві завжди прагнуть актуалізуватися у відносинах влади символічної, а символ стає ключовим знаряддям у боротьбі за монополію на легітимне світобачення. Позаяк, звертаючись до механізму впровадження певної системи цінностей, міфологем та символів, можна організувати задане сприйняття соціального світу а, значить, i сам світ, і встановити у цьому світі правила та норми, за якими будуть конструюватися та відтворюватися соціальні відносини. Вкрай важливо у цьому зв’язку те, що символічне домінування дозволяє не тільки реалізовувати контроль над громадською думкою, але й, у перспективі, забезпечує контролювання процесів соціалізації майбутніх поколінь.

Це спостереження чітко віддзеркалюється у нинішній постполітичній ситуацій. Адже сьогодні релігія та ідеологія остаточно втратили статус ключових джерел символічного виробництва та лідерські позиції у арсеналі інструментів смислоутворення. У добу постсучасності їх місце поступово та невідворотно займає нова практика - політичний соціосеміозис. Його сутність полягає у механізмі універсалізації практик інтерпретації політичної реальності та ㄲi феноменів, результатом якого і стає символізм політичного простору. Таким чином, політичний соціосемозис остаточно перетворює політичний порядок на порядок символічний, де створюються мережеві ієрархії сутностей світу політики через техніки інтерпретації.

Даний висновок чітко простежується у широкій присутності у символічному ландшафті постполітики архетипових проекцій таких архаїчних духовних практик, як тотемізм та фетишизм. Як похідна від ритуалу, фетиш має безпосереднє відношення 
до тотему, а разом вони складають підоснову усієї предметної політичної символіки: від фізико-географічний об'єктів, репрезентантів світу фауни і флори до архітектури, монументалістики та атрибутів державного суверенітету як об'єктів культу та колективних оберегів.

Сдність людини i космосу, закладена в основу міфологічного світосприйняття породжують явище анімізму та його продукти - тотем і фетиш. Через систему заборон (табу) тотем встановлює не тільки норми колективного співіснування (групової моралі), але й задає правила соціальних змагань (гри), які дозволяють людини включитися у боротьбу за символічне домінування. Як символічна першоформа тотем надав життя біологічній символіці предметного блоку символічного комплексу ідентифікації - представникам фауни і флори, які через архетипові проекції набули статусу покровителів народів та неофіційних символів держав.

Фетишизм як звичай поклоніння матеріальним предметам надав життя ще декільком типам символіки предметно ряду. Так об'єктно-символічні фетиші породили фізико-географічну символіку як складову предметного блоку символічного комплексу ідентифікації (ріки, озера, гори тощо), а символічно-об'єктні фетиші (рукотворні ідоли) - монументалістику та архітектуру.

Отже, символотворення є невід'ємною складовою соціального буття людини, а широка смуга ipраціональності зумовлює та робить невідворотнім звернення до символічного виробництва у будь-яку іс- торичну епоху на будь-якому етапі розвитку моделей соціально-політичної організації суспільства, в тому числі й у ситуації постполітики.

\section{СПИСОК ВИКОРИСТАНИХ ДЖЕРЕЛ}

1. Ионин Л. Г. Тотем / Л. Г. Ионин// Новая философская энциклопедия в 4 т. Т. 4. “Т-Я”. Институт философии РАН. М.: Мысль, 2001. C. 81-82.

2. Lévy-Bruhl Lucien Le surnaturel et la nature dans la mentalité primitive / Lucien Lévy-Bruhl. - P.: Puf, 1963. 568 p.

3. Выготской Л. С. Мышление и речь / Л. С. Выготской (Изд. 5, испр.) М.: Лабиринт, 1999. - 352 с.

4. De Brosses Charles, Du Culte Des Dieux Ftiches: Ou Parallle de L'Ancienne Religion de L'Egypte Avec La Religion Actuelle de Nigritie / CharlesDe Brosses. - P.: Nabu Press, 2010. 298 p.

5. Tylor Edward Burnett Primitive Culture: Researches Into the Development of Mythology, Philosophy, Religion, Language, Art and Custom (V. 1) (1903 ) / Edward Burnett Tylor. Cornell University Library, 2009. 522 p.

6. Маркс К. Об атеизме, религии и церкви [Сборник], / К. Маркс, Ф. Энгельс. М.: Мысль, 1986. 670 с. (Серия: Научно-атеистическая библиотека).

7. Маркс К. Капитал. Критика политической экономии. Том 1. / К. Маркс, Ф. Энгельс. Избранные произведения в 9 т.: Т. 7. М.: Изд-во политической литературы, 1984. 812 с.

8. Беньямин В. Париж - столица XIX века / В. Беньямин; [пер. с франц.] // Историко-философский ежегодник. Ин-т философии. М.: Наука, 1990. М., 1991. С. 235-247. 
9. Сорокин П. Словесный фетишизм революции / П. Сорокин // Заметки социолога: социологическая публицистика (Сочинения). СПб.: Алетейа, 2000. С. 151-153.

10. Бурдье П. Делегирование и политический фетишизм/ П. Бурдье // Социология политики; [пер. с франц. сост., общ. ред. и предисл. H. А. Шматко] M.: Socio-Logos, 1993. C. 231-262.

\section{REFERENCES}

1. Ionin, L. G. (2001). Totem [Totem]. Novaya filosofskaya entsiklopediya v 4-kh tomakh. T. 4. "T - Ya” [New philosophical encyclopedia in 4 volumes. Vol. 4. "T - Ya"]. (pp. 81-82). Moscow: Mysl [in Russian].

2. Lévy-Bruhl, L. (1963). Le surnaturel et la nature dans la mentalité primitive. Paris: PUF [in French].

3. Vygotskoy, L. S. (1999). Myshlenie i rech [Thinking and Speech] (5th ed., rew.) Moscow: Labirint [in Russian].

4. De Brosses, C. (2010). Culte Des Dieux Fétiches: Ou Parallle de L'Ancienne Religion de L'Egypte Avec La Religion Actuelle de Nigritie. Nabu Press [in French].
5. Burnett, T. E. (2009). Primitive Culture: Researches into the Development of Mythology, Philosophy, Religion, Language, Art and Custom. (Vols. 1). Cornell University Library [in English].

6. Marx, K., Engels, F. (1986). Ob ateizme, religii i tserkvi [On atheism, religion and the church]. Moscow: Mysl [in Russian].

7. Marx, K., Engels, F. (1984). Kapital. Kritika politicheskoy ekonomii [A Critique of Political Economy]. (Vols. 1). Moscow: Izdatelstvo politicheskoy literatury [in Russian].

8. Benjamin, V. (1991). Parizh - stolitsa XIX veka [Paris, capital of the 19th century]. Istoriko-filosofskiy ezhegodnik - Historical and Philosophical Yearbook, 235-247 [in Russian].

9. Sorokin, P. (2000). Slovesnyy fetishizm revolyutsii [Verbal Fetishism of the Revolution]. Zametki sotsiologa: sotsiologicheskaya publitsistika - Notes of a sociologist: sociological journalism. (pp. 151-153). Saint Petesburg: Aleteya [in Russian].

10. Bourdieu, P. (1993). Delegirovanie i politicheskiy fetishizm [Delegation and Political Fetishism]. (N. A. Shmatko, Trans.). (pp. 231-262). Moscow: Socio-Logos [in Russian]. 